\title{
CHEMICAL COMPOSITION AND ANTIBACTERIAL ACTIVITY OF ESSENTIAL OILS FROM AZORELLA SPINOSA (APIACEAE) AGAINST WILD PHYTOPATHOGENIC BACTERIA
}

\author{
ADRIANA JARA-BERMEO ${ }^{a}$ PATRICIO PEÑAILILLO ${ }^{b}$, AURELIO SAN-MARTÍN ${ }^{c, d}$, OMAR MALAGON $^{e}$ \\ GIANLUCA GILARDONI , MARGARITA GUTIÉRREZ ${ }^{*}$
}

\author{
${ }^{a}$ Instituto de Química de Recursos Naturales, Universidad de Talca, Talca, Chile \\ ${ }^{b}$ Instituto de Ciencias Biológicas, Universidad de Talca, Talca, Chile \\ 'Departamento de Química, Facultad de Ciencias, Universidad de Magallanes, Punta Arenas, Chile \\ ${ }^{d}$ Departamento de Química, Facultad de Ciencias, Universidad de Chile, Chile \\ ésección Química Básica y Aplicada, Departamento de Química, Universidad Técnica Particular de Loja, Loja, Ecuador.
}

\begin{abstract}
The aim of the present investigation was to appraise variation in the chemical composition and antimicrobial activity against phytopatogenic bacterial of essential oils from Azorella spinosa. Three samples of $A$. spinosa were collected in different date in the same area. The essential oils were obtained for hydrodestillation using a Clevenger-type apparatus. The chemical composition of essential oils were analysed using Gas chromatography-mass spectrometry showed variation in the yield and composition, the main detected compounds were monoterpenes such as limonene $(10.66-12.30 \%)$, tricyclene (10.81-16.99\%) and sabinene (9.10-11.49\%), the most abundant sesquiterpene was $\gamma$-gurjenene (5.48-8.47\%). The biological activity of essential oils from $A$. spinosa against wild phytopatogenic microorganisms showed selectivity over Pseudomonas syringae. This is the first report of the essential oil composition of $A$. spinosa, and confirms that natural products obtained from aromatic plants represent an important source of bioactive molecules that could be used as new alternatives for the treatment of phytopatogenic bacteria infections.
\end{abstract}

Keywords: Antimicrobialactivity, Azorella spinosa, essential oils.

\section{INTRODUCTION}

Essential oils also called volatile odoriferous are aromatic and natural complex mixture of compounds obtained from different parts of vegetables, such as flowers, peels, barks, leaves, roots, stems, seeds and so on ${ }^{1}$. Essential oils are known to be important antimicrobial agents present in plants, and they may also have antioxidant and anti-inflammatory activities ${ }^{2,3}$. In nature, the essential oils play important roles in protection of plants to microorganisms. Several studies report the variation of chemical composition of the essential oil according to environmental conditions such as climate, soil, solar radiation, etc $^{4,5}$. The composition of essential oils are dominated by terpenes, mainly monoterpenes, sesquiterpenes, and their oxygenated derivatives such as alcohols, aldehydes, esters, ethers, ketones, and phenols, which have antitumor, antioxidant, anti-aging, antimutation, and sedative effects, ${ }^{6,7,8}$. In addition, the high content of phenolic derivatives of essential oils contributes to their antimicrobial properties ${ }^{9}$. The use of essential oil of different species has been reported as antimicrobial over different strains, including phytopatogenic microorganisms ${ }^{10,11,12,13,14}$.

Many factors determine the composition and yield of the essential oil obtained. In some instances it is difficult to segregate these factors from each other, since many are interdependent and influence one each other. These factors include seasonal and maturity variation, geographical origin, genetic variation, growth stages, part of plant utilized and postharvest drying and storage ${ }^{15,16,17}$.

Azorella Lam. is a genus of the Apiaceae (Umbelliferae) represented by ca. 70 species growing in Andes and temperate South America and Antarctica Islands ${ }^{18}$. It is commonly known "yareta" or "llareta". In Chile, these species are distributed from the high Andes in the north to Isla Navarino, in the southern part of South America ${ }^{19,20}$. In traditional medicine, infusions of all plants are used as stomach stimulants and many extracts and infusions are diuretic, analgesics, used in the treatment of migrane and neuralgia, pneumonia and rheumatism ${ }^{21}$. Also, aqueous extracts showed effectivity in diabetes associated with obesity ${ }^{22}$. These species are recognized for producing unique diterpenoid structures having the novel mulinane and azorellane skeletons with a wide variety of interesting biological activities ${ }^{23}$.

However, research related to the essential oils obtained from these species, is restricted to A. cryptantha(Clos) Reiche ${ }^{24}$ and A. trifurcata(Gaertn.) Pers. ${ }^{25}$ from San Juan, Argentina. In this study, we compared temporal variation of chemical composition of essential oils from A. spinosa(Ruiz et Pav.)collected in the coastal mountains of central Chile and the antimicrobial activity of the oils obtained.

\section{MATERIALS AND METHODS}

\section{Chemicals}

3-[4,5-dimethylthiazol-2-yl]- 2,5-diphenyltetrazolium bromide (MTT) resazurin, homologous series of $\mathrm{C}_{9}-\mathrm{C}_{28} n$-alkanes and others references chemicals used in this study were obtained from Sigma Chemical Co (St Louis, MO, USA), penicillin/strepomicin were obtained from Laboratory Chile, Santiago, Chile. All other chemicals (Analytical grade) used in this study were purchased from Merck (Darmstadt, Germany), unless stated other wise. All culture media were purchased from Gibco (BRL, Scotland).

Plant Material

Samples of A. spinosa were collected during November of 2014; January and April of 2015, in Pantanillo, near Constitution in Maule Region of Chile (geographical coordinates $35^{\circ} 43$ 'and $35^{\circ} 47^{\prime}$ 'south latitude; and $72^{\circ} 29^{\prime}$ ' and $\left.72^{\circ} 31^{\prime}\right)$. A voucher specimen was deposited in the herbarium of University of Talca (Voucher $\mathrm{n}^{\circ} 3360$ ).

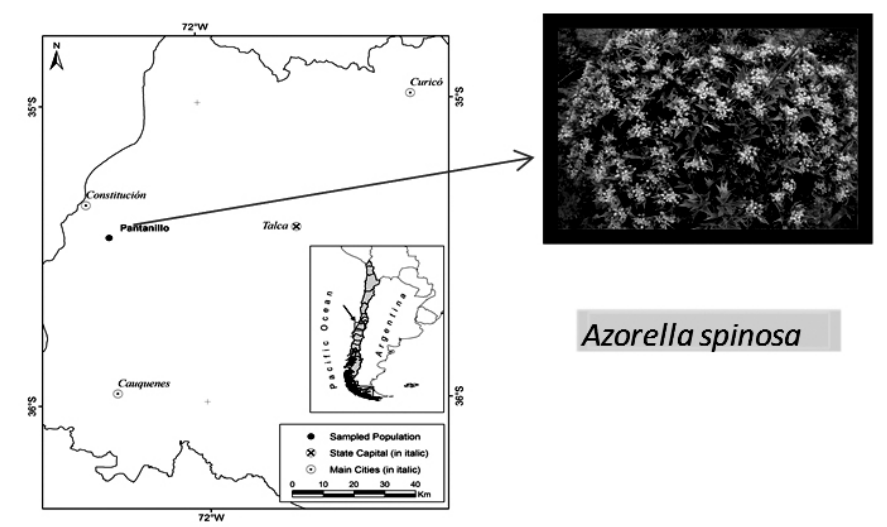

Figure 1. Geographical location of the collection area to A.spinosa

Extraction of essential oils

The essential oils were obtained by steam distillation ( $300 \mathrm{~g}$ of fresh plant) during $1 \mathrm{~h}$ in the Cleavenger-like apparatus, dried over anhydrous sodium sulfate $\left(\mathrm{Na}_{2} \mathrm{SO}_{4}\right)$, filtered and stored at $4{ }^{\circ} \mathrm{C}$ until tested and analyzed using methodology previously descrite ${ }^{24-26}$. 


\section{GC-MS/ GC-FID analysis conditions}

The essential oils were analyzed by GC/FID using an Agilent Technologies $6890 \mathrm{~N}$ equipped with a FID detector witha fused DB-5 MS capillary column ( $30 \mathrm{~m} \times 0.25 \mathrm{~mm}$ i,d, film thickness $0.25 \mu \mathrm{m}$ ) and by using nitrogen as a carrier gas (45 psi). The split injection mode was selected. Samples were analyzed at oven temperature programmed: initial temperature was $50^{\circ} \mathrm{C}$ (held for $5 \mathrm{~min}$ ), $5^{\circ} \mathrm{C}$ min to $220^{\circ} \mathrm{C}$ (held $10 \mathrm{~min}$ ). Diluted samples $(5 \%$ in dichloromethane, $\mathrm{v} / \mathrm{v})$ of $1 \mu \mathrm{L}$ were injected automatically in split 50:1

The samples are also analyzed by gas chromatography Agilent Technologies $6890 \mathrm{~N}$, equipped directly to Detector Agilent Technologies 5973 inert Mass Selective Mass Spectrometer (GC/MS) equipped with a DB-5 MS (same as above) and by using helium as a carrier gas (49.6 psi), a flow rate of $1 \mathrm{~mL} / \mathrm{min}$. Samples were analyzed at oven temperature programmed: initial temperature was $60^{\circ} \mathrm{C}$ (held for $5 \mathrm{~min}$ ), $5^{\circ} \mathrm{C}$ min to $250^{\circ} \mathrm{C}$ (held $10 \mathrm{~min}$ ). $1 \mu \mathrm{L}$ of diluted samples $(5 \%$ in dichloromethane, $\mathrm{v} / \mathrm{v})$ were injected were injected automatically in split 40:1. The mass spectrometer was operated in electron impact mode with the electron energy set at $70 \mathrm{eV}$ and a scan range of 45-350 $\mathrm{m} / \mathrm{z}$.

Samples were analyzed under same conditions, the standard (mixture of n-alkane $\mathrm{C}_{9}-\mathrm{C}_{28}$ homologues) were used to calculate retention indices (RI), were according to the RI Van den Dool and Kratz equation, and the mass spectra identification was confirmed by electronic Wiley 7 mass spectral data base and literature ${ }^{27}$.

\section{Microbial Strains}

\section{Antibacterial activity}

Microorganisms collection of bacterial isolated: Bacterial cultures used in the present study were isolated from infections plant and were classificated in the phytopathology laboratory of Universidad de Talca.

Maintenance of bacterial cultures: All the bacterial isolates were cultured and maintained in LB(Luria Bertain) medium (1\% tryptone, $1 \%$ sodium chloride, $0.5 \%$ yeast extract) during all the experiments of the study until mentioned. The bacterial cultures were refreshed fortnightly.

Antibiotic used: The antibiotics used in this investigation were: penicillin $\mathrm{G}$ and streptomycin. The control strains were run simultaneously with the test organisms.

Preservation of isolates: Glycerol stocks were prepared and stored at $-80^{\circ}$ $\mathrm{C}$ for long term preservation. Pure cultures strains were incubated at $37^{\circ} \mathrm{C}$ for $48 \mathrm{~h}$ in isolation broth. Then $0.5 \mathrm{~mL}$ of each of the cultures was transferred into cryotubes and $0.5 \mathrm{~mL}$ broth containing $40 \%$ glycerol was added. The samples were mixed gently and stored at $-80^{\circ} \mathrm{C}$

Determination of Antibacterial Activity: Antibacterial assays against phytopatogenic bacterial Erwinia carotovora subsp. carotovora(Jones 1901) Dye 1969, isolated from pepper (Capsicum aпnиum L., Solanaceae); Clavibacter michiganensis subsp. michiganensis(Smith 1910) isolated from tomato (Solanum lycopersicum L., Solanaceae), Xanthomonas sp. isolated from bean (Phaseolus vulgaris L., Fabaceae) and Pseudomonas syringae(van Hall 1902) isolated from tomato, the assays were carried out using the doubling dilution in 96-well microtiter plates using MTT (3-[4,5-dimethylthiazol-2-yl]2,5-diphenyltetrazolium bromide $)^{28}$ and resazurin (7-Hydroxy- $3 \mathrm{H}$-phenoxazin3-one 10 -oxide $)^{29}$ as revelator:

MTT assay: Bacterial suspensions were obtained from overnight cultures in Luria Broth Base nutrient broth cultured at $25^{\circ} \mathrm{C}$ and diluted to approximately $10^{5}$ colony-forming units $(\mathrm{CFU}) /$ well in fresh medium. The compounds were dissolved to produce $2.5 \mathrm{mg} / \mathrm{mL}$ in Luria Broth as a stock solution. Stock solutions of compounds were diluted to give serial 2-fold dilutions that were added to each medium resulting in concentrations ranging from 1042 a $65.13 \mu \mathrm{g} / \mathrm{mL}$. The samples were prepared in triplicate and the plates were kept at $25^{\circ} \mathrm{C}$ overnight $(12 \mathrm{~h})$. After incubation, $20 \mu \mathrm{L}$ of $0.5 \mathrm{mg} / \mathrm{mL}$ aqueous MTT (Sigma Chemical Co., St. Louis, MO) was added in each well and reincubated for $30 \mathrm{~min}$ to detect living bacteria. Each plate was wrapped loosely with cling film to ensure that bacteria did not become dehydrated. Each plate had a set of controls: a column with a positive control; a column with all solutions with the exception ofthe test compound; a column with all solutions with the exception of the bacterial solution adding nutrient broth instead. The growth was indicated by color changes from yellow to blue (Figure 2). The lowest concentration at which color change occurred was taken asthe MIC value.
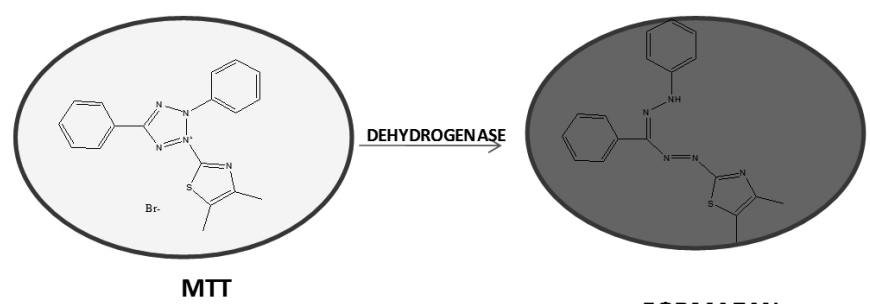

FORMAZAN

Figure 2. Change in color from MTT and MTT Formazan

Resazurin assay: from stock solution of essential oil two fold dilutions of each sample were prepared directly in the plate. One hundred microliters of inoculum was added to each well. A growth control and a sterile control were also included for each plate. The plates were kept at $25^{\circ} \mathrm{C}$ overnight. After incubation, $20 \mu \mathrm{L}$ of resazurin solution $(0.01 \%)$ was added to each well, and the plate was re-incubated for $30 \mathrm{~min}$. A change in color from blue to pink indicated the growth of bacteria (Figure 3), and the minimal inhibitory concentration (MIC) was defined for each strain as the lowest concentration of the oil that had no color change. A change in color of growth control well to pink indicated the proper growth of the isolate and no change in color of sterile control well indicated absence of contaminants.

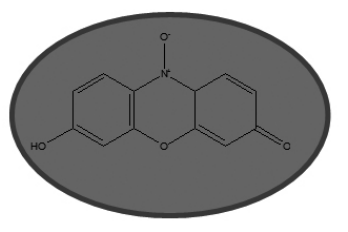

REDUCTASE $\stackrel{\text { REDUCTASE }}{\longrightarrow}$

\section{RESAZURIN}

Figure 3. Change in color from resazurin and resorufin.

\section{RESULTS AND DISCUSSION}

Azorella spinosa was collected in three times at different date in Mediterranean central Chile and processed to obtain essential oils. Table 1 showed yield and density of essential oil of A. spinosa collected in different time. The result obtained showed the amount of essential oil produced by the plant can be modified by external factors such as climate and internal like plant phenology ${ }^{30}$. The general yield of these specie is low compared with reports for A. trifurcata and A. cryptanta from San Juan, Argentina, described previously others authors where it is reported composition of essential oil in the range of 21 to $0.2 \%^{23,24}$, however our analysis showed yield of 12 to $0.03 \%$. This is the first report that the essential oil composition of $A$. spinosa. The results obtained suggest that the contituents are principally the same for three collections studied, with any differences in minor constituents. In general the genus Azorella grows in poor soils, which could indicate that these plant components serve as protection against desiccation, high solar radiation and unfavorable weather and geographical conditions due to highly specialized physiological processes that affect their chemical response ${ }^{30}$. These reach from the synthesis of special lipids that modify cell membranes for flexibility and $\mathrm{H}_{2} \mathrm{O}$ permeability to other features like the cushion-growth form of $A$. spinosa as a way of reducing extreme temperatures and $\mathrm{H}_{2} \mathrm{O}$ fluctuations, process not seen in low-altitude plants ${ }^{31}$.

Table 1. Date, yield and density of oils obtained

\begin{tabular}{|c|c|c|c|c|}
\hline $\begin{array}{c}\text { Date collection } \\
\text { Month and Year }\end{array}$ & $\begin{array}{c}\text { Material } \\
(\mathrm{g})\end{array}$ & Oil $(\mathrm{mL})$ & Yield $(\%)$ & $\delta(\mathrm{g} / \mathrm{mL})$ \\
\hline November 2014 & 2688 & 0.3 & 0.011 & 0.87 \\
\hline January 2015 & 1742 & 0.3 & 0.017 & 0.86 \\
\hline April 2015 & 1596 & 0.5 & 0.031 & 0.84 \\
\hline
\end{tabular}

As showed in the table 2, 25 majoritary compounds of the essential 
oils obtained from A. spinosa were identified by GC/MS analysis, $40 \%$ corresponds to monoterpenes and $60 \%$ to sesquiterpenes. The main compounds were monoterpenes such as limonene (10.66-12.30\%), tricyclene (10.81$16.99 \%)$ and sabinene $(9.10-11.49 \%)$. The most abundant sesquiterpene was $\gamma$-gurjenene (5.48-8.47\%). Only one monoterpene (10\%) was oxigenated and six sesquiterpenes was oxigenated (24\%). Previously study realized with $A$. cryptanta from Argentina showed abundance of monoterpenes where the major were $\alpha$-pinene and thujene ${ }^{24}$. However tryciclene was the major component independent of the date of collection. Experimental evidences described in literature confirm a similar activity due to tryciclene, therefore the high presence of this compound is compatible with the proved antibacterial activity, for example, the essential oil of Cordia cylindrostachya (Ruiz et Pav.) Roem. $\&$ Schult. (Boraginaceae) grown on Aruba showed a high content of tricyclene (ca. 58\%), $\alpha$-pinene (ca. 11\%) and camphene (ca. 12\%). The oil showed weak antibacterial and antifungal activities ${ }^{31}$. In the same manner in $2009^{33}$ is reported antibacterial activity of the essential oil of C. curassavica (Jacq) Roem.\&Schult, that grows in Mérida-Venezuela, where the most abundant constituents were tricyclene, similar situation is described in $2011^{34}$, for essential oil from Gossypium barbadense L. (Malvaceae). This information may suggest that responsible for the antibacterial activity can be tryciclene or the antimicrobial activities of an essential oil may be due to the major components or synergy between major and minor compounds ${ }^{35}$.

Table 2. Components identified in the essential oils of A. spinosa (\%) using GC-MS/GC-FID.

\begin{tabular}{|c|c|c|c|c|}
\hline Compounds (name) & RT & $\begin{array}{c}\text { November }(\%) \\
2014\end{array}$ & $\begin{array}{c}\text { January (\%) } \\
2015\end{array}$ & $\begin{array}{c}\text { April (\%) } \\
2015\end{array}$ \\
\hline \multicolumn{5}{|c|}{ Monoterpenes } \\
\hline Tryciclene & 4.40 & $10.81 / 5.81$ & $12.40 / 12.09$ & $16.99 / 10.74$ \\
\hline$\alpha$-Pinene & 4.86 & $0.52 / 0.21$ & $0.71 / 0.56$ & $0.98 / 0.51$ \\
\hline Sabinene & 5.70 & $9.10 / 5.22$ & $10.14 / 9.42$ & $11.49 / 6.92$ \\
\hline$\beta$-Pinene & 5.86 & $7.40 / 4.60$ & $9.06 / 9.27$ & $0 / 11.75$ \\
\hline Myrcene & 6.34 & $3.09 / 2.34$ & $3.87 / 4.51$ & $3.59 / 0.02$ \\
\hline Iso-Silvestrene & 7.01 & $1.83 / 0.94$ & $1.48 / 1.26$ & $1.67 / 0.21$ \\
\hline p-Cymene & 7.72 & $1.77 / 1.36$ & $1.03 / 0.92$ & $1.49 / 0.86$ \\
\hline Limonene & 7.93 & $12.30 / 6.45$ & $11.53 / 10.60$ & $10.77 / 7.05$ \\
\hline$\gamma$-Terpinene & 9.14 & $1.24 / 0.40$ & $1.77 / 1.29$ & $1.41 / 0.78$ \\
\hline Terpinen-4-ol & 11.42 & $1.91 / 1.76$ & $3.67 / 3.46$ & tr./ 1.85 \\
\hline \multicolumn{5}{|c|}{ Sesquiterpenes } \\
\hline$\alpha$-Copaene & 23.26 & $0.43 / 0.33$ & $0.81 / 0.64$ & $1.03 / 0.78$ \\
\hline Modheph-2-ene & 23.95 & $2.59 / 2.56$ & $1.60 / 1.80$ & $3.95 / 0.60$ \\
\hline 2-epi- $\beta$-Funebrene & 25.06 & $2.90 / 2.67$ & $3.33 / 2.90$ & $2.69 / 2.43$ \\
\hline$\beta$-Duprezianenen & 25.83 & $1.71 / 1.58$ & tr./tr & $\operatorname{tr} / / \mathrm{tr}$ \\
\hline 2 -epi- $\beta$-santalene & 26.50 & $3.88 / 3.47$ & $2.50 / 2.17$ & $2.02 / 1.62$ \\
\hline$\gamma$-Gurjenene & 27.66 & $5.69 / 4.01$ & $8.47 / 6.53$ & $5.48 / 4.29$ \\
\hline$\gamma$-Curcumene & 28.21 & $2.41 / 1.46$ & $2.09 / 1.77$ & $1.60 / 1.13$ \\
\hline Viridiflorene & 28.70 & $4.70 / 3.20$ & $2.53 / 1.77$ & $4.79 / 3.45$ \\
\hline$\gamma$-Cardinene & 29.23 & $0.85 / 0.51$ & $1.87 / 1.40$ & $1.46 / 1.14$ \\
\hline Spathulenol & 31.46 & $1.39 / 1.61$ & $0.73 / 0.76$ & $2.10 / 1.84$ \\
\hline Palustrol & 31.54 & $0.66 / 0.67$ & $0.97 / 0.89$ & $2.23 / 2.21$ \\
\hline$\alpha$-Cedrene epoxido & 31.80 & $3.37 / 3.06$ & $0.61 / 0.54$ & $0.63 / 0.54$ \\
\hline Cedrol & 32.63 & $0.53 / 0.64$ & $0.52 / 0.89$ & $1.20 / 1.13$ \\
\hline$\alpha$-Muurol & 34.51 & $0.99 / 0.81$ & $1.05 / 0.88$ & $1.42 / 0.58$ \\
\hline Ageratochromene & 35.03 & $0.31 / 0.15$ & $0.48 / 0.37$ & $1.10 / 0.59$ \\
\hline Total & & 82.38 & 83.25 & 80.04 \\
\hline Monoterpenes (\%) & & 40 & 40 & 32 \\
\hline Sesquiterpenes (\%) & & 60 & 60 & 60 \\
\hline Ox.Monoterpenes (\%) & & 10 & 10 & 0 \\
\hline Ox. Sesquiterpenes (\%) & & 33.33 & 33.33 & 33.33 \\
\hline
\end{tabular}

RT: Retention index relative to $n$-alkanes on DB-5 capillary column; Ox: oxigenated;tr: trace, less than 0.05 . 
The oils obtained in January and April was evaluated as potential antibacterial agents against phytopatogenic microorganisms, the oil obtained in November was obtained a low yield and was used in order to standardize the working conditionsof GC/MS.

The antibacterial activities of $A$. spinosa oils were evaluated against phytopatogenic microorganisms, showed a low activity using MTT as revelator, however the oil from A. spinosa of two sample evaluated showed activity againts P.syringae with MIC value of $130.25 \mu \mathrm{g} / \mathrm{mL}$ using resazurin as revelator, these results showed a selectivity of oils for $P$. syringae, resazurin (blue and nonfluorescent) is reduced to resorufin (pink and highly fluorescent) by oxidoreductasa, therefore color change is an indicator of enzimatic function.

Under our assay conditions, the MIC values of streptomycin and penicillin $\mathrm{G}$ used as control, against $P$. syringae were 11.1 and $15.6 \mu \mathrm{g} / \mathrm{mL}$, respectively, while for E. carotovora subsp. carotovora the values were 15.6 and $122.7 \mu \mathrm{g} /$ $\mathrm{mL}$, for Xhantomonas sp. 18.3 and $95.7 \mu \mathrm{g} / \mathrm{mL}$ and 34.2 and $77.4 \mu \mathrm{g} / \mathrm{mL}$ for $C$. michiganensis subs. Michiganensis.

The production of essential oils and aromatics from plants is variable under diverse physiological, biochemical, metabolic and genetic regulation. The physiological regulation, besides being exerted in a development-specific fashion, is highly susceptible to modulation through environmental regulation. Biochemical and metabolic processes comprise the molecular mechanisms that regulate carbon flow through the biosynthetic routes, as well as the turnover rate of the relevant terpenoid and/or phenylpropanoid metabolism. The genotype-related nature and magnitude of these interactive responses form the genetic controls ${ }^{36}$.

Temperature variation generates an increase in oil content of $A$. spinosa. The main oil production is represented by the presence of monoterpenes in the three cases. The increase in the concentration of compounds in the oils may be related to preparing the plant for the cold season in which is practically it disappears from the surface while maintaining its roots underground which generate shoots again in the period in which increases temperature, this increase can generate a reservation for this time.

In general, essential oils are characterized by two or three major components at fairly high concentration $(>20 \%)$. Generally, these compounds determine the biological properties of the oils ${ }^{25}$. The chemical composition of plants can be subject to quantitative and qualitative variation, however biological activity is similarly subject to variation ${ }^{36,37,38}$. In this study $A$. spinosa was collected in the same place but at different times and years, however, in the same period spring summer of southern hemisphere. Compared the collection the differences in the yield, quantity and composition of the essential oils can be attributed to different factor such as climate, solar radiation or phenological state of the plant.

In addition, the oil of $A$. spinosa displayed moderate antimicrobial activities against $P$. syringae compared with the standard. The antimicrobial activities of an essential may be due to the major components or synergy between major and minor compounds.

This is the first time that the essential oils of A. spinosa has been reported, Twenty- five compounds of the total oil were identified in different season of the year between November 2014- April 2015.

\section{CONCLUSION}

In general, harvesting season can affect chemical compositiona as well as the biological activity of essential oils; the results obtained indicate that A. spinosa present a minor variation in chemical composition; however, oils have selectivity and moderate activity againtst phytopatogenic bacterial. The information obtained show potential of $A$. spinosa oils for used in natural therapies for the treatment of infectious diseases in plants, and the information observed on seasonal variation may be useful in selecting the best season for optimal yield and presence of bioactive compounds.

\section{Conflict of interest statement}

We declare that we have no conflict of interest

\section{ACKNOWLEDGEMENTS}

We would like to express our gratitude to scholarship CONICYT 63130234, Fondecyt project 1120199 for its financial support and PIEI-QuimBio at the University of Talca. Authors wish to thank Ing. James Calva for him help in the technical support in the GC-MS analysis. Also public institution Corporación Nacional Forestal CONAF.

\section{REFERENCES}

1. K.H.C. Bașer; Gerhard Buchbauer. Handbook of essential oils: science, technology, and applications, CRC press Taylor \& Francis Group, (2010).

2. R. Amorati, M.C. Foti, L. Valgimigli. J. Agric. Food Chem.61, 10835, (2013).

3. M.M. Gomes, A.B. Miltojević, N.S. Radulović, I.R. Abdul-Wahab, F.Boylan, P. Dias. PLOS ONE | DOI:10.1371/journal.pone.0121063 March 25, (2015)

4. S. Zouari, I. Ayadi, N. Fakhfakh, H. Jdir, L.Aloui, M. Kossentini, A. Rebai N. Zouari. Bot. Stud.55, 76, (2014).

5. A. Gil, E. B. De La Fuente, A. E. Lenardis, M. Lopez Pereira, S. A. Suarez, A. Bandoni, C. van Baren, P. Di Leo Lira, C. M. Ghersa.J. Agric. Food Chem.50, 2870, (2002).

6. B. Bayala, I.H. Bassole, R. Scifo, C. Gnoula, L. Morel, J.M.A. Lobaccaro, J. Simpore.Am.J. Cancer Res. 4,591, (2014).

7. N. Gautam, A. K.Mantha, S. Mittal.Biomed Res. Int. doi:10.1155/2014/154106, (2014).

8. S. Aazza, B. Lyousii, C. MegíasI.Cortés-Giraldo, J. Vioque, A.C. Figueiredo, M.G.Miguel.Nat Prod Commun. 9, 587, (2014).

9. V. Aleksic, P. Knezevic. Microbiol. Res. 169, 240, (2014).

10. R. Kotan, F. Dadasoglu, K. Karagoz, A. Cakir, H. Ozer, S. Kordali, R. Cakmakci, N. Dikbas. Sci. Hortic.153, 34, (2013).

11. K. Abhay, P.P. Singh, U.T. Palni, N.N. Tripathi. J. Serb. Chem. Soc. 77, $313,(2012)$

12. R. Kotan, A. Cakir, F. Dadasoglu, T. Aydin, R. Cakmakci, H. Ozer, S. Kordali, E. Mete, N. Dikbas. J. Sci. Food Agric.90, 145, (2010).

13. A. Gormez, S. Bozari, D. Yanmis, M. Gulluce, F. Sahin,G. Agar. Pol J.Microbiol. 64, 121, (2015).

14. M.de las M. Oliva, M.E. Carezzano, M. Giuliano, J. Daghero, J. Zygadlo, P. Bogino, W. Giordano, M. Demo.Plant Biol. 17, 758, (2015).

15. K. Saeb, S. Gholamrezaee. Asian Pac. J. Trop. Biomed.2, 547, (2012).

16. A.C. Atti-Santos, M.R. Pansera, N. Paroul, L. Atti-Serafini, P.P. Moyna.J. Essential oil Res. 16, 294,(2004).

17. F. Anwar. J. Herbs Spices and Med Plan.15, 1,(2009).

18. J.W. Byng. 2014. The flowering plants handbook: A practical guide to families and genera of the world. Plant Gateway Ltd. Hestford. UK. 518519

19. F.C. De Baldarrago, I. Poma, V. Spadaro. Quad. Bot. Amb. App.23, $15,(2012)$.

20. O. Muñoz, M. Montes, T. Wilkomirsky. Monografias plantas medicinales de uso en Chile, Química y farmacología. Editorial Universitaria S.A., (1999).

21. C. Villagrán, M. Romo, V. Castro. Rev. Antropol. Chil.35, 73,(2003).

22. N. L. Fuentes, H. Sagua, G. Morales, J. Borquez, A. San-Martin, J. Soto, L. A Loyola. Phytother. Res. 19, 713, (2005).

23. L.A. Loyola, J. Borquez, G. Morales, A. San-Martın, J. Darias. Tetrahedron Lett.43, 6359, (2002).

24. S. Lopez, B. Lima, L. Aragon, L. Ariza, A. Tapia, S. Zacchino, J. Zygadlo, G. Feresin, M. Lopez. Chem. Biodivers.9, 1452, (2012).

25. S. Lopez, B. Lima, M. B. Aguero, M. L. Lopez, M. Hadad, J.Zygadlo, D. Caballero, R. Stariolo, E. Suero, G. E. Feresin, A. Tapia. Arabian J. Chem. (2014) doi:10.1016/j.arabjc.2014.11.022.

26. D. Hernandez, J. Orozco,R. Serrano, A. Duran, S. Meraz, M. JimenezEstrada, A. Garcia-Bores, G. Avila, T. Hernandez. Blacpma 13, 100, (2014).

27. R.P. Adams. Identification of essential oil components by gas chromatography/mass Spectrometry, Edn 4, AlluredPubl Co, Carol Stream. IL (2005).

28. M. Gutierrez, C. Theoduloz, J. Rodriguez, M. Lolas, and G. SchmedaHirschmann. J. Agr.Food Chem.53, 7701, (2005).

29. R.A. Khalifa, M.S. Nasser, A.A. Goma, N.M.Osman, H.M. Salem Egypt. J.Chest Dis. Tuberc. 62, 241, (2013).

30. B.L. Sampaio, R.A. Edrada-Ebel, F.B. Da Costa. Sci. Rep. 6, 29265 , (2016).

31. C. Kleier, P. Rundel.Plant Biol.11, 351, (2009).

32. C. E. Fun, A. BaerheimSvendsen. J. Essent. Oil Res. 2, 209, (1990).

33. G. Meccia, L.B. Rojas, J. Velasco, T. Díaz, A. Usubillaga, J.C. Arzola, S. Ramos.Nat. Prod. Commun. 4, 1119, (2009)

34. E.E. Essien, S.O. Aboaba, I.A.Ogunwande.J. Med. Plants Res.5, 702, (2011).

35. Burt, S. Int. J. Food Microbiol.94, 223, (2004)

36. N.S. Sangwan, A.H.A. Farooqi, F. Shabih, R.S. Sangwan. Plant Growth Regul.34, 3, (2001)

37. A.I. Hissain,F. Anwar, P.S. Nigam, M. Ashraf, A.H. Hilani. J. Sci. Food Agric.90, 1827, (2010).

38. G.E. Wickens. Econ.bot. 49, 207, (1995). 